\title{
POTENTIAL OF NATA DE LEGEN IN IMPROVING LOCAL WELLNESS OF NATURAL RESOURCES AND HUMAN RESOURCES IN DALEGAN VILLAGE, GRESIK DISTRICT
}

\author{
Mahanani Tri Asri ${ }^{*}$, Nur Ducha², Evie Ratnasari ${ }^{3}$, Ahmad Bashri ${ }^{4}$ \\ Biology-FMIPA-Surabaya State University \\ *email : mahananiasri@unesa.ac.id
}

\begin{abstract}
Dalegan Village of Gresik District, East Java, is a large Legen / neera and Palmyra fruit producing village. During this time legen siwalan was sold in the form of natural drinks. The problem faced by partners at this time is this Palmyra fruit spoils relatively quick so it doesn't have high selling value. A technology is needed in the form fermentation to produce Nata de Legen using Acetobacter xylinum. Training method used were in form of lectures, demonstrations, discussions, direct practice, independent tasks, evaluation and marketing trials. The training was conducted in 3 groups consisting of 10 Local Welfare Organization (PKK) members and 5 Youth Organization members. The expected output target at the end of the program is that all participants succeeded in making the starter and Nata de Legen correctly. Participants also managed to whiten and soften raw Nata, which then made into end-products in the form of fruit-flavored Nata de Legen drinks (honeydew, strawberry, orange and cocopandan) and desserts in form of jelly and pudding packed in cup and bulk with the selling price calculated accordingly to Nata de Legen entrepreneurial training.
\end{abstract}

Keywords: Nata de Legen, local wellness, natural resources, Dalegan village

\section{INTRODUCTION}

Palmyra Palm (Borassus flabellifer)is native to the Indian subcontinent and Southeast Asia, including Indonesia (Kazi, et al., 2017). Based on observations conducted in Gresik, Dalegan village, Shoberoh Hamlet, has large area of Palmyra fruit plantation. The majority of population owns land planted with Palmyra, therefore most of the villagers in Dalegan make living by selling Palmyra fruit, especially Legen from Palmyra neera. The problems faced by farmers and sellers are Legen and Palmyra fruit don't last long and spoil quickly, if they are not sold within a few days they will be spoiled and thrown away. This causes loss to farmers and sellers. Application of technology is needed as an effort to use Palmyra neera (Legen) into another food products that have more selling value and could increase profit for farmers and sellers. The technology chosen is applying fermentation to produce Nata deLegen.In general, the production of nata isdone by direct inoculation into liquid medium. Immobilization of cells is a technique used to trap the cells into a matrix. The useof immobilized cells for the production of nata is one alternative to the product resulted in a cell-free nata sel (Nugroho dan Aji, 2015), Nata is a bacterial cellulose formed from 


\section{Website : http://jurnal.untan.ac.id/index.php/JPLP2KM ISSN : $2620-4665$ (print) \\ ISSN : $2620-4673$ (online)}

bacterial activity (Budiyanto, 2000), with Acetobacter xylinummetabolizes glucose and convertsit into bacterial cellulose that has unique properties including high purity, crystallinity and mechanical strength (Halib, dkk. 2012), Cellulose products produced by aerobic bacteria (Acetobacter xylinum) get much attention because of their unique physicochemical properties compared to plant cellulose, including their application in the food industry (Esa, dkk. 2014). Legen that has been processed into Nata deLegen has high potential and selling value so that it can elevate the status of Shoberoh hamlet to become a business center for Nata deLegen with producers who are skilled and creative in processing Nata deLegen into various food and beverage products.

The process of making Nata deLegen from Palmyra fruit is an effort to increase the economic value of Legen, which so far has only been used to make Legen drinks, which not everyone likes, because of its high alcohol content. Nata is a processed food product good for health for its high fiber which is useful to help digestive process of food. It also has high economic value and profitable because the production process requires simple ingredients and low cost.Nutrient content of palmyra neera consists of water $(87.66 \%)$, sugar $(12.04 \%)$, protein $(0.36 \%)$, fat $(0.36 \%)$, and ash $(0.21 \%)$. The result of processing isotonic drinks with a combination technique obtained sugar content of $10.4-16.3 \%, \mathrm{pH} 4.0-4.3$, as well as the smell and taste of the preferred category until very preferred (Gafar dan Heryani, 2012). Different results on mesocarp of Palmyra fruit showed a water content of $77.31 \%$, total fat $0.11 \%$, ash $1.43 \%$, tannin $0.08 \%$, total carotenoids $8324.6 \mu \mathrm{g} /$ $100 \mathrm{~g}$, carotene $6217.48 \mu \mathrm{g} / 100 \mathrm{~g}$ (Idayati dkk, 2014). Another technique for preserving nata is using the drying method. Nata samples were dried using three physical drying methods such as oven, tray dryer or freeze dryer until it achieved 3-5\% moisture content (Pa'e et. al., 2014).

The problems faced by farmers and sellers of Legenwas that it conducts natural fermentation in a short time which causedLegen to spoil, tastes sour, and smells of alcohol so it does not sell and will be eventually thrown away. This caused lost for farmers and sellers. One effort to reduce losses from spoiledLegenis processing it into other products, e.g. liquid or solidpalm sugar which have long production process and uses a lot of fuel but have low selling value. Therefore, Community Service Project (CSP) conducted trainingofanother technologyto utilize spoiled Legen into other food products that have higher selling value and increase profit for farmers and sellers. The technology implemented to increase value ofLegen was conventional biotechnology in form fermentation to process Legen into Nata deLegen using Acetobacter xylinum. 
Website : http://jurnal.untan.ac.id/index.php/JPLP2KM ISSN : $2620-4665$ (print)

ISSN : $2620-4673$ (online)

\section{METHODS}

Training methods for making de Legen Nata divided into three group of participants, namely Melati Mandiri group (consisted of 5 members from Shoberoh hamlet Local Welfare Organization (PKK) in Dalegan Village), Mawar Mandiri group (consisted of 5 members from Shoberoh hamlet Local Welfare Organization (PKK) in Dalegan Village), and Tunas Mandiri group (consisted of 5 members from Shoberoh hamletYouth Organization in Dalegan Village). The training was carried out in stages: lectures, demonstrations, discussions, direct practice, independent assignments, evaluation and marketing trials. Lectures was conducted to deliver information related to nutritional content and the benefit of Palmyra fruit neera, the method of making Nata de Legen from neera, the benefits of Nata de Legen for health, the presentation and marketing technique, and entrepreneurial management. Demonstration was conducted after lectures. UNESA PKM team demonstrated the procedures of Nata de Legen production using Legen from Palmyra fruit, starter Acetobacter xylinum, and tools and materials for the production. With demonstrations, it is expected that participants can understand the stages of the implementation of Nata de Legen better. Discussions were conducted face-to-face during lectures, as well as during demonstrations on the training of making Nata de Legen. Discussions were expected to make things related to techniques of making Nata de Legen clearer and not participants would not hesitate to make it independently. Discussions were also conducted as an activity to exchange experiences for both the PKM Team itself and participants. Direct practice was conducted after lectures and demonstrations. Members from each group practice the stages of making Nata de Legen. Independent assignments were conducted individually by all group members, making Nata de Legen by providing their own ingredients, except for Acetobacter xylinum starter given by the Unesa PKM team. Post-harvesting process of Nata de Legen was conducted by making food and beverage products for sale. Results from independent assignments would be then evaluated by the UNESA PKM team. 
Website : http://jurnal.untan.ac.id/index.php/JPLP2KM ISSN : $2620-4665$ (print)

ISSN : $2620-4673$ (online)

\section{RESULTS AND DISCUSSION}

The training for Nata de Legen production for partner groups in Shoberoh Village, Dalegan Village consisted of 4 stages, those were preparation, training, results monitoring, and finished product.

\subsection{PREPARATION STAGE}

Preparations included: surveying the training locations, purchasing training tools and materials, making training material guidebook, trial of Nata de Legen starter production, trial of Nata de Legen production, trial of Nata de Legen production for various food and beverage products, trial of packaging of food / beverage products made from Nata de Legen, all conducted in Biology Department-FMIPA-UNESA.

In the location survey, information obtained were names and number of training participants, as follows:

Table 1. Participants of starter and Nata de Legen production, Shoberoh Hamlet, Dalegan Village, Gresik District, East Java

\begin{tabular}{lll}
\hline Group Name & Member Name & Position \\
\hline Mawar Mandiri & Anita & Leader \\
& Sumrotin & Member \\
& Mufarrohah & Member \\
& Etik Izarotin & Member \\
& Zuliyatin & Member \\
Melati Mandiri & Luluk Enifah & Leader \\
& Wenisatul habibah & Member \\
& Zuanatul Afifah & Member \\
& Enik Mu'awarah & Member \\
Tunas Mandiri & Mukholifah & Member \\
& Saiful Rohman & Leader \\
& Mohamad Nursholeh & Member \\
& Wahyudi AdiNata & Member \\
& Mohamad Yanto & Member \\
& Ahmad Farid Zamzami & Member \\
\hline
\end{tabular}




\section{Website : http://jurnal.untan.ac.id/index.php/JPLP2KM ISSN : $2620-4665$ (print) \\ ISSN : $2620-4673$ (online)}

The second preparation phase was conducted in Surabaya,that was purchasing tools and materials, and the third preparation stage in the form of making training material guidebook in the form of 1. Making Nata de Legen, processed products of Nata and supplementary materials, entrepreneurial management models and simple financial bookkeeping. The fourth stage of preparation was making Nata de Legen starter with result of sterile Acetobacter xylinum growing well in Legen medium with $1 \mathrm{~cm}$ thickness of nata in the surface after 7 days incubation (Figure 1C).

The next preparation stage is the trial of making Nata de Legen with starter produced from Legen medium. This stage was conducted in UNESA Microbiology Laboratory with good results obtained. Nata de Legen produced had tender texture, light brown (cream) color with a weight of $800-900 \mathrm{gr} /$ liter medium and thickness of 1 to $1.5 \mathrm{~cm}$ in 7-9 days incubation. The trial of making beverage products was conducted in UNESA Microbiology Laboratory by making simple drinks and desserts in form of fruit-flavored Nata and Nata pudding to give example for participants and to motivate their creativity.
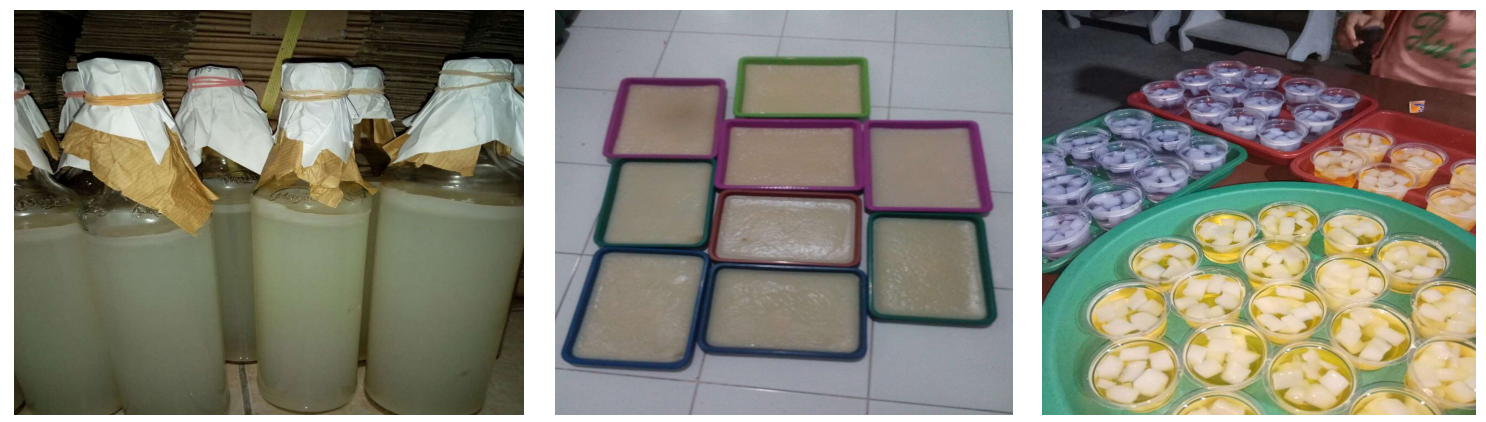

Figure 1. A. Starter Nata de Legen, B. Nata de Legen, C. Examples of Nata de Legen beverage products produced at the preparation stage

\subsection{STARTER AND NATA DE LEGEN PRODUCTION TRAINING STAGE}

The training activities went through several phases, those were the distribution of training material, the making of starter, the harvesting of starter production continued with the practice of making Nata de Legen, post-harvest production of processed Nata de Legen finished products.

In the first phase, this training was preceded by delivering general information of Nata de Legen, namely (1) theoretical introduction to the Nata de Legen starter and Nata de Legen forming bacteria Acetobacter xylinum, (2). Sterilization of necessary equipment (3) Procedure for making starter Nata de Legen. Delivery of the material was followed by demonstration of the starter Nata 
Website : http://jurnal.untan.ac.id/index.php/JPLP2KM ISSN : $2620-4665$ (print)

ISSN : 2620 - 4673 (online)

de Legen production and direct practice of making Nata de Legen. Participants take steps to make the Nata de Legen starter as shown in Table 2.

Table 2. Stages for making starter Nata de Legen by participants

\begin{tabular}{|c|c|c|}
\hline NO. & STAGE & DETAILS \\
\hline 1. & $\begin{array}{l}\text { Preparation of tools and } \\
\text { materials and sterilization } \\
\text { (starter bottles) }\end{array}$ & Bottles sterilization was conducted using oven stove \\
\hline 2. & $\begin{array}{l}\text { Making of growing medium } \\
\text { for Acetobacter xylinum } \\
\text { (starter) }\end{array}$ & Boiling with stove until $100 \% \mathrm{C}$ \\
\hline 3. & $\begin{array}{l}\text { Inoculation of starter into } \\
\text { prepared medium }\end{array}$ & $\begin{array}{l}\text { Inoculation was conducted aseptically (in condition to prevent } \\
\text { contamination from pathogens) }\end{array}$ \\
\hline 4. & Starter incubation & $\begin{array}{l}\text { Acetobakter xylinum in medium grew in temperature between } \\
28^{\circ}-30^{\circ} \mathrm{C} \text { for } 7-9 \text { days }\end{array}$ \\
\hline 5. & $\begin{array}{l}\text { Observation of starter } \\
\text { growth }\end{array}$ & $\begin{array}{l}\text { Good starter was indicated by formation of nata in the surface } \\
\text { of medium approximately } 1 \mathrm{~cm} \text { thick }\end{array}$ \\
\hline
\end{tabular}

At the stage of starter production, it took around 7 to 9 days to get starter that could produce optimum Nata de Legen due to Acetobacter xylinum required incubation time of about 7-9 days. So the next training was conducted 7 days later.

The second phase of this training was conducted 7 days after the participants made the starter. The result was shown in Figure 2. From 15 participants, all could produce the Nata de Legen starter well. There was no contamination, nata formed in thesurface of the bottle was $1 \mathrm{~cm}$ thick, the medium became cloudy and smelled sour.

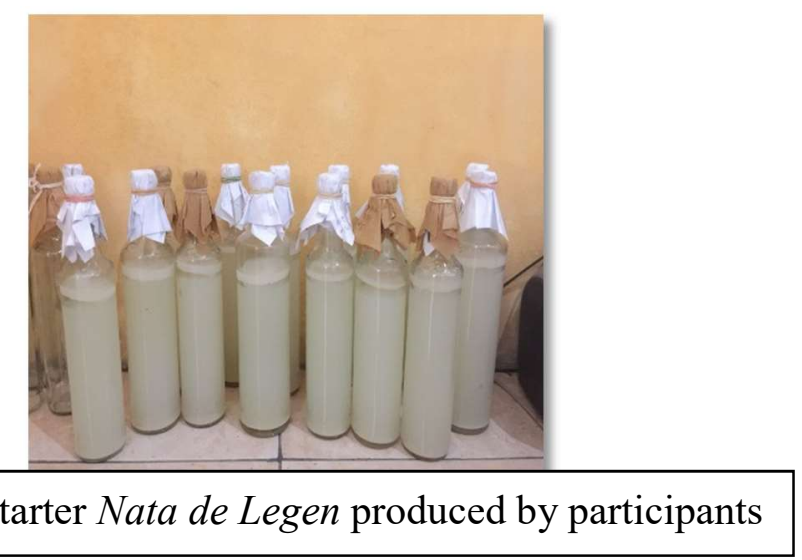




\section{Website : http://jurnal.untan.ac.id/index.php/JPLP2KM ISSN : $2620-4665$ (print) \\ ISSN : $2620-4673$ (online)}

The training could be continued to make Nata de Legen because the starter was produced well and no contamination. But before the practice of making Nata, the participants were given the material about making Nata de Legen beforehand. The contents of the material consist of (1) theoretical study of Palmyra Legen and its formation process, (2) preparation of tools and materials, (3) sterilization of tools and materials, (4) procedures for making Nata de Legen medium, (5) starter inoculation on the medium tray, incubation and observation of results. The training continued with demonstrations and direct practice for participants. The stages of making Nata de Legen can be seen in Table 3:

Table 3. Stages of Nata de Legen Production

No. Stage Details

1. Preparing tools and materials

The main tools used were trays and cooking tools, and the main ingredients was Legen

2. Making Nata de Legen

Palmyra neera, sugar, minerals, and vinegar is boiled on a medium stove

3. Tray Sterilization Boiled medium then poured onto tray (1 litre) and covered with parchment paper and cooled

4. Inoculation of starter into $10 \%$ of Acetobacter xylinum starter is poured into cool medium

Medium consisted of starter was incubated in room

5. Incubation of medium temperature for 10-12 days covered with parchment paper or newspaper.

6. Harvesting Nata de Legen Harvesting was conducted if nata was formed maximally (no media is left) with $1-1.5 \mathrm{~cm}$ thickness.

Nata was cut with kitchen knife, softened with caustic soda

7 Cutting, softening, and whitening of Nata de Legen or baking soda, and whitened by submerging in water for long period of time.

\subsection{MONITORING PHASE OF NATA DE LEGEN PRODUCTION}

The monitoring phase was conducted after the medium Nata had been inoculated with Acetobacter xylinum was incubated for 7 days. The results of monitoring during the making of Nata de Legen showed that almost all participants had no problems and did not experience difficulties, because of the 15 participants produced sheets of Nata on the tray well with no contamination. From 1 liter medium a thickness of about $0.8-1 \mathrm{~cm}$ nata were produced. 

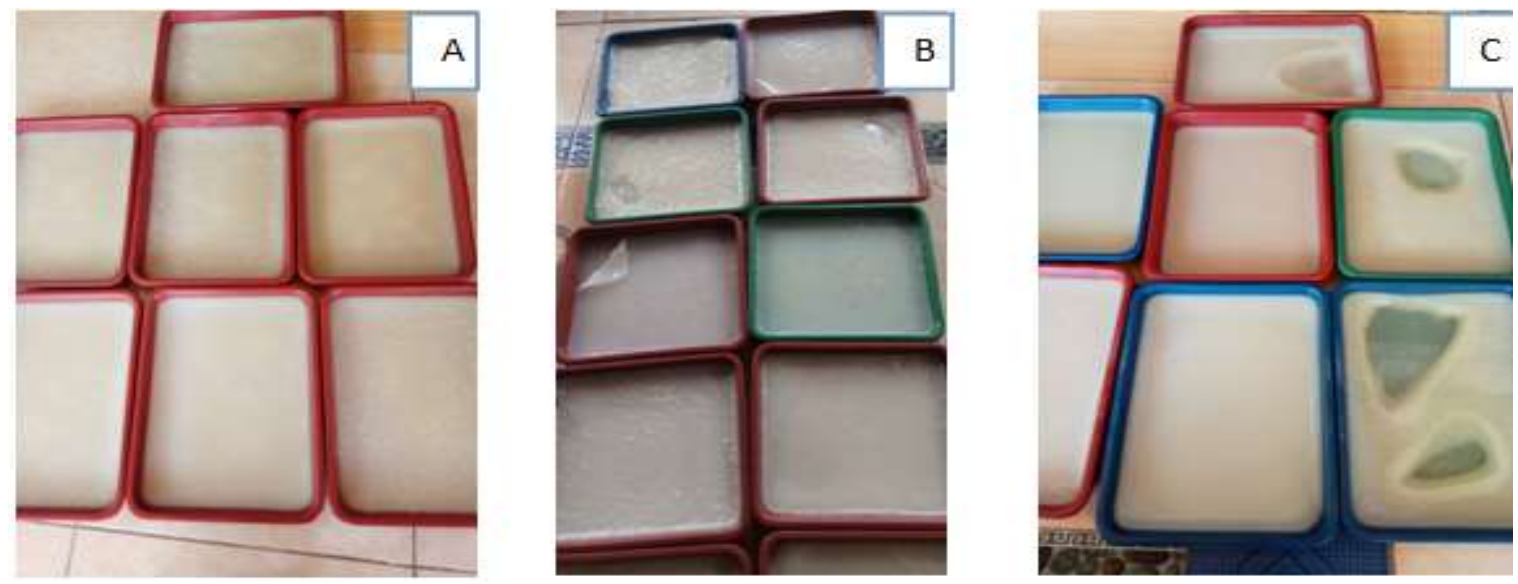

Figure 3. Nata de Legen in tray/sheets produced by participants (A) smooth surface (B) varied surface (c) holes in sheets

The weigh of the Nata were around 800 to 900 grams / liter medium. The texture of Nata produced were smooth with regular fibers, chewy and has a brownish (creamy) white color and smells acidic, although there were some that have wavy surfaces and holes but had contamination (Figure 4). Result of Nata de Legen production is shown in Table 4.

Table 4. Monitoring of Nata de Legen production

\begin{tabular}{|c|c|c|c|}
\hline No & Group & Member & Nata de Legen \\
\hline \multirow[t]{5}{*}{1.} & Mawar Mandiri & Anita & Succeed / Nata is formed \\
\hline & & Sumrotin & Succeed / Nata is formed \\
\hline & & Mufarrohah & Succeed / Nata is formed \\
\hline & & Etik Izarotin & $\begin{array}{l}\text { Succeed / Nata is formed but the } \\
\text { surface is not smooth }\end{array}$ \\
\hline & & Zuliyatin & Succeed / Nata is formed but thin \\
\hline \multirow[t]{5}{*}{2.} & Melati Mandiri & Luluk Enifah & Succeed / Nata is formed \\
\hline & & Wenisatul Habibah & Succeed / Nata is formed \\
\hline & & Zuanatul Afifah & Succeed / Nata is formed with holes \\
\hline & & Enik Mu'awarah & Succeed / Nata is formed \\
\hline & & Mukholifah & Succeed / Nata is formed \\
\hline \multirow[t]{5}{*}{3} & Tunas Mandiri & Saiful Rohman & Succeed / Nata is formed \\
\hline & & Mohamad Nursholeh & Succeed / Nata is formed \\
\hline & & Wahyudi Adinata & Succeed / Nata is formed with holes \\
\hline & & Mohamad Yanto & Succeed / Nata is formed with holes \\
\hline & & Ahmad Farid Zamzami & Succeed / Nata is formed \\
\hline
\end{tabular}




\section{Website : http://jurnal.untan.ac.id/index.php/JPLP2KM ISSN : $2620-4665$ (print) \\ ISSN : $2620-4673$ (online)}

The morphology of the non-smooth surface of the Nata was caused by uneven mixing of Acetobacter xylinum in inoculation step (how to flatten medium by rocking the tray). The holes in Nata was caused by the tray cover (brown paper) that was not neatly placed so that it touched the medium, the area touched by brown paper did not allow $A$. xylinum to produce Nata properly. However, the areas affected by the brown paper were not contaminated because the paper was still new (sterile). Besides, the medium which was high in acidity (pH 3) and acted as selector for the microbial environment / microbes that might be on the sticky brown paper.

\section{POST HARVEST PRODUCTION PHASE}

Nata formed in the trays were immediately harvested and washed with water to remove the sour odor. The lowest layer of Nata was also removed to eliminate remnants of the media. The Nata then cut into cubes or rectangles of appropriate size (generally $1 \times 1 \mathrm{~cm}$ ) and the Nata was then soaked in water for whitening and reducing sour smell for 3 days. Every day the water was replaced before the next process, those were pressing and bleaching. Bleaching was done by soaking the Nata in $0.5 \%$ caustic soda $(\mathrm{NaOH})$ solution for 24 hours. Nata was washed many times until the alkali properties disappeared (surface was not slippery) and the $\mathrm{pH}$ had returned to neutral $(\mathrm{pH}$ 7). Soften Nata was indicated if it was tearable or lose fiber when bitten. The bleached and softened Nata was then boiled and ready for the finished product (Figure 4)
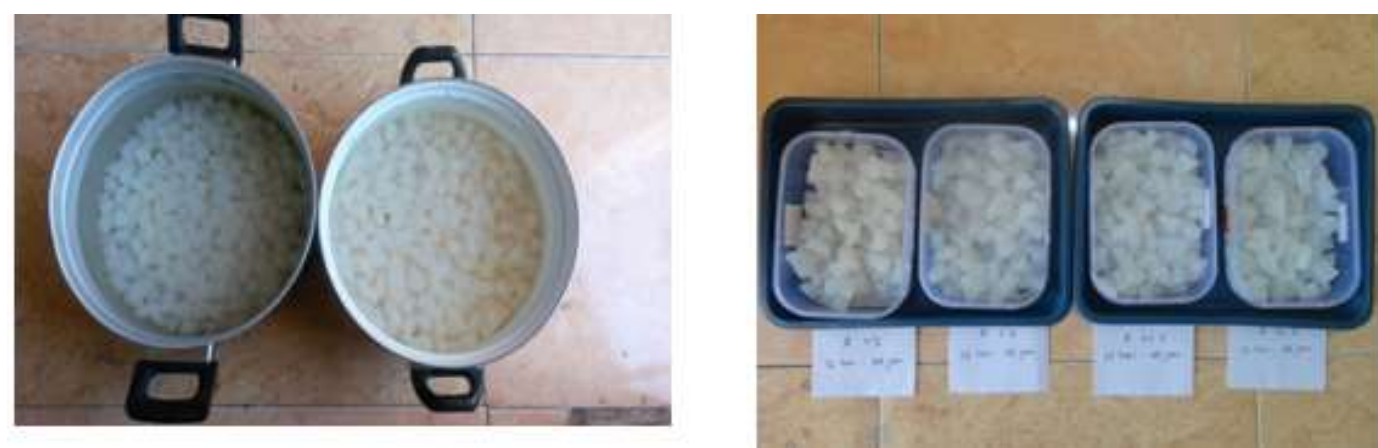

Figurer 4. Post harvesting production: Nata cut into rectangles $(\mathrm{A})$ and whitening of Nata de Legen (B) 
Website : http://jurnal.untan.ac.id/index.php/JPLP2KM

ISSN : $2620-4665$ (print)

ISSN : $2620-4673$ (online)

\subsection{PRODUCTION PHASE OF NATA DE LEGEN PROCESSED PRODUCTS, ADDITIONAL MATERIALS USED AND PACKAGING METHODS}

The results of direct practice of making Nata de Legen were then processed to become food and drink. Food and beverage products made were desserts and beveragess that were much preferred by people. The beverage products fruit-flavored Nata drinks such as oranges, strawberry, cocopandan and honeydew. Nata de Legen was mixed in syrup and water typical of children's favorites. Besides that, participants were also taught to make jelly or Nata de Legen pudding with various colors and flavors with additives such as food colorings and preservatives according to standards of government regulations, and packaging was using cup sealers and hand sealers. Pictures of beverage and food products that were trained as shown in Figure 5.
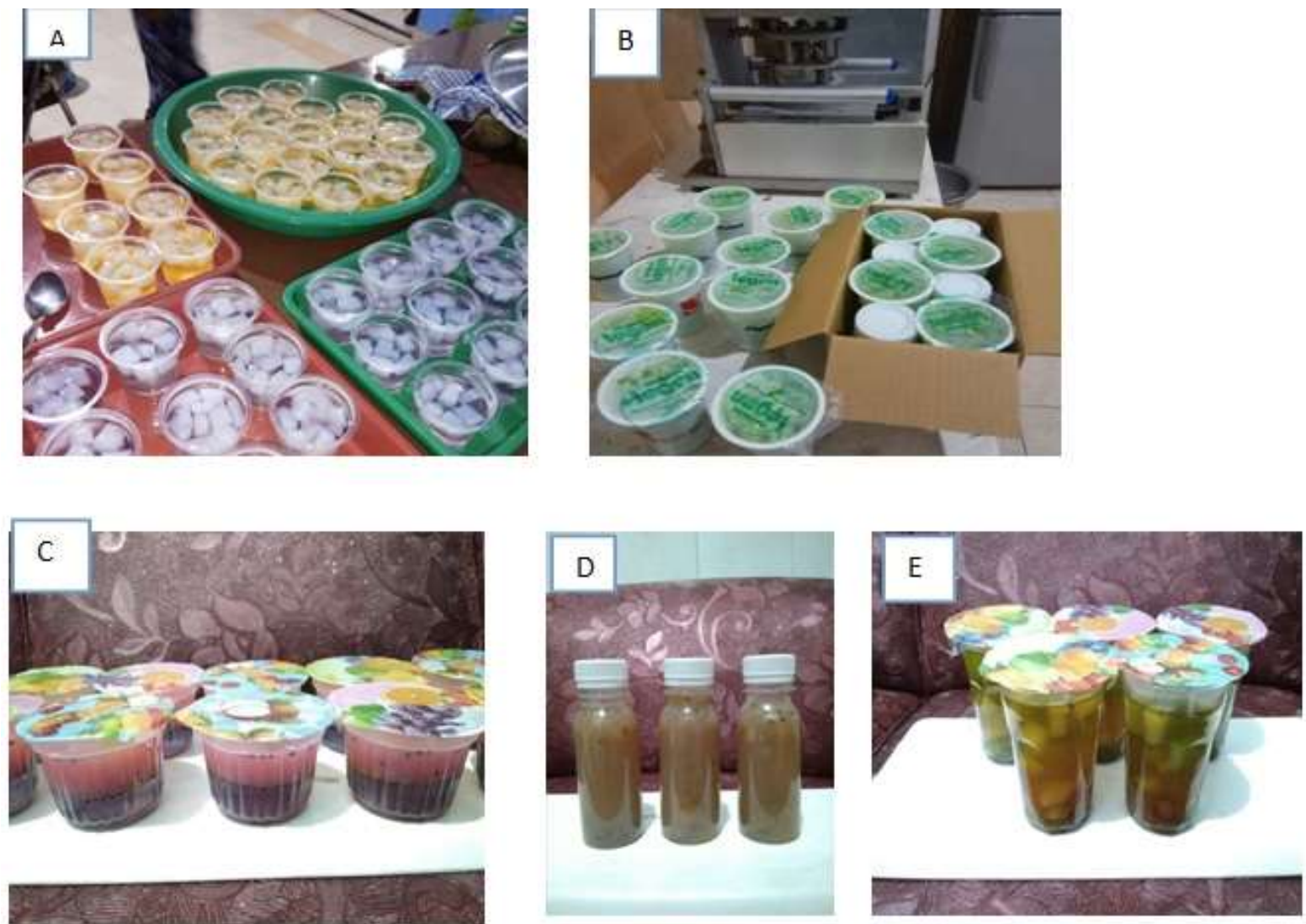

Figure 5. Various processed products (A. nutrijel Nata of various flavors. B. Honeydew flavored drinks C. Mixed flavor Nata jelly D. Pudding drink and E. Fruit mixed Nata drink 


\section{Website : http://jurnal.untan.ac.id/index.php/JPLP2KM ISSN : $2620-4665$ (print) \\ ISSN : $2620-4673$ (online)}

Training activities started with preparation, implementation and monitoring were conducted as planned. Prior to the implementation of the training activities, preparations were made which included preparation of training materials for making starter and Nata de Legen, food coloring, food flavor additives, food preservative, entrepreneurial material, preparation of tools and materials, reinforcement of starter and Nata production methods, trial of starter and Nata production, and trial of processing Nata de Legen into food and beverages. Marketing trials were also conducted.

Preparations were conducted well because all the tools and materials needed for training were available accordingly to the needs for training, the material delivered had also been well arranged before the training, and a coherent method has been obtained for the production of starter and Nata de Legen. Starter preparation trial were conducted in a microbiology laboratory. The trial of starter production aimed to obtain Acetobacter xylinum using Palmyra neera/Legen medium, because the original medium for this bacteria was coconut water. If the bacteria adapted to the Legen medium, starter was expected to be reproduced in Palmyra Legen medium so that it could be harvested in large quantities repeatedly. The trial showed that the starter formed with the characteristics white chewy mass on the surface of the medium in the starter bottle. The white chewy mass was called Nata de Legen, while the rather cloudy liquid below was called starter. This starter could be used to make Nata de Legen or to reproduce starter again with the Palmyra Legen medium. Palmyra Legen could be used as a medium for making Nata because it has composition similar to coconut water. According to Davis and Johnson (1987), Palmyra Legen contains total sugar $(\mathrm{g} / 100 \mathrm{cc})=10.93 ;$ Protein $(\mathrm{g} / 100 \mathrm{cc})=0.35$; Nitrogen $(\mathrm{g} / 100 \mathrm{cc})=0.056$; Phosphorus $(\mathrm{g} / 100 \mathrm{cc})=0.14 ; \operatorname{Iron}(\mathrm{g} / 100 \mathrm{cc})=0.4 ; \operatorname{Vitamin} \mathrm{C}(\mathrm{mg} / 100 \mathrm{cc})=13.25$.

The high content of nutrients in Legen is suitable to be processed into Nata. Nata de Legen has smooth surface, white color, and high-fiber texture. Using Acetobacter xylinum, the liquid form of Legen could be converted into cellulose fiber sheets that were chewy and could be used as a mixture for drinks or packaged foods. Nata de Legen drinks were no less delicious when compared to Nata de Coco. The results of the trial then used for making nata to be demonstrated to the participants.

The trial of making Nata de Legen obtained good results with the characteristics of Nata which formed thickness following the height of the medium, for 1 liter medium which was poured on a tray with a height of about $1 \mathrm{~cm}$, Nata thickness ranged from $0.8-1 \mathrm{~cm}$. The weight of the Nata produced also corresponded to the volume of the medium. The medium used was about 1 liter. 


\section{Website : http://jurnal.untan.ac.id/index.php/JPLP2KM ISSN : $2620-4665$ (print) \\ ISSN : $2620-4673$ (online)}

From 1 liter of medium, around 800 to 900 grams of Nata was obtained. The texture of the Nata produced was smooth with regular fibers, chewy with brownish white (creamy) color and smells acidic, although there were some that have a bumpy or hollow surface. Based on these results, it was indicated that Legen from Palmyra could be used as a medium for making Nata, and the results were not much different in quality with Nata made from coconut water. This showed that Legen composition with coconut water was similar, so that it could be used optimally for the production of Nata.

Training went according to plan, all participants were enthusiastic in participating in the activities, from giving material to direct practice. This happened because the training method was not monotonous. Each speaker presented materials along with demonstration activities, which showed direct examples and demonstrated how to use or work on the production.

During direct practice activities, all participants were enthusiastic in each stage both to make starter and Nata de Legen. One week later, an evaluation of the resulted starter and the Nata de Legen from the participants was conducted. The evaluation results showed that the production of starter and Nata de Legen was succeed, in accordance with the standards. This showed that the training material was well understood, and the participants had mastered the stages of the starter and Nata de Legen production methods. This could happen because during the demonstration stage, participants not only saw the demonstration, but they were also given the opportunity to join. All participants were given tools and materials to try directly. They were also given opportunity to ask if there were things they did not understand. The participants were also felt free and not awkward to ask two students who helped with the training activities. Thus there was two-way communication, so the training material could be absorbed properly.

After evaluating the results of direct practice of starter and Nata de Legen production, the next stage was the preparation of processing Nata de Legen into food and beverage products. The results showed that the food and beverage preparations made by the trainees are very varied and with good quality, tasted good and with presentable appearance. Food and beverages made by participants were suitable for sale in the community, because they tasted quite good, and did not contain food additives prohibited by the government. The coloring used was food coloring and the content was low. The sweetener used was real sugar and did not use artificial sweeteners that were dangerous to health, so that food and drinks were safe for consumption. From the sale of processed products in the Delegan beach tourism area and the product bazaar, it showed that the 
Website : http://jurnal.untan.ac.id/index.php/JPLP2KM ISSN : 2620 - 4665 (print)

ISSN : $2620-4673$ (online)

people around the beach tourism and tourists liked their local products Nata de Legen according to successful marketing.

\section{CONCLUSION AND RECOMENDATION}

\subsection{CONCLUTION}

a. The participants have succeeded in producing starter and Nata de Legen with good results and according to standards

b. The participants have succeeded in producing varied food and beverage preparations using Nata de Legen as basic ingredient, with a good taste and presentable appearance. Processed products were liked by public.

c. Participants gained knowledge and skills to produce Nata de Legen from Legen so it increased the economic value of Legen.

\subsection{REKOMENDATION}

Further community service program is needed in the form of preservation of nata de legen processed products to be durable in the market, as well as the mechanization of the process of making nata de legen

\section{ACKNOWLEDGEMENTS}

Our thanks to DRPM through the PKM scheme for PPDM as a funder of this PKM.

\section{REFERENCES}

Kazi AA, Tandel MB, Pathak JG, Prajapati DH. 2017. Potentiality of Colocasia Intercrop Under Naturally Occurring Palmyra Palm(Borassus flabellifer L.). Journal of Tree Sciences 36 (1): 58-61.

Nugroho DA, Aji P. 2015. Characterization of Nata de Coco Produced by Fermentation oflmmobilized Acetobacter xylinum. Agriculture and Agricultural Science Procedia 3: 278282.

Budiyanto, M. A. K. 2002. Mikrobiologi Terapan. Malang: Universitas Muhammadiyah Malang.

Halib N, Amin MCIM, Ahmad I. 2012. Physicochemical Properties and Characterization of Nata de Coco fromLocal Food Industries as a Source of Cellulose. Sains Malaysiana 41(2): 205211. 
Website : http://jurnal.untan.ac.id/index.php/JPLP2KM ISSN : $2620-4665$ (print)

ISSN : $2620-4673$ (online)

Esa F, Tasirin SM, Rahman NA. 2014. Overview of Bacterial Cellulose Production and Application. Agriculture and Agricultural Science Procedia 2: 113-119.

Gafar PA., Heryani S. 2012. The development of Aren sap drink processing technology by using ultrafiltration and deodorization techniques. Jurnal Hasil Penelitian Industri 25 (1): 1-10.

Idayati E, Suparmo, Darmadji P. 2014. Potency of Mesocarp Bioactive Compounds in Lontar Fruit (Borassus fl abeliffer L.) as A Source of Natural Antioxidant. Agritech34 (3): 277-284.

Pa'e N, Hamid NIA, Khairuddin N, Zahan KA, Seng KF, Siddique BM, Muhamad II. 2014. Effect of Different Drying Methods on the Morphology, Crystallinity, Swelling Ability and Tensile Properties of Nata de Coco. Sains Malaysiana 43(5): 767-773.

Davis LS, Johnson KN. 1987. Forest Management. Third Edition. New York: McGrawHill Book Company. 